\title{
PROLOGUE
}

\section{Meals Before Money}

\section{Restaurant in a Garden}

This was the place for a lazy Sunday lunch ... once you had wound up from the city into the hills, found the garden path to an old, two-story stone home, and entered a dining room sheltering beside a venerable pear tree. The summer menu included zucchini flowers picked by the restaurateur that morning, globe artichokes cut by a cook out the window, and more than abundant raspberries from down steps for one month every year. The prosciutto and mortadella were cured by a local family, and the small growers' wines would never be mass advertised. Rather than mood music, the room relied on the occasionally raucous, sometimes silent, but often sublime hum and clink of dining.

I have eaten at some great restaurants. They have taught me much, and I thank them-a few appear in this book. But I learned most from this small and not especially famous restaurant, the Uraidla Aristologist, where, in the Adelaide Hills, South Australia, I was coproprietor with Jennifer Hillier through the 1980 and into the 1990 .

Our fascination with meals (and my exhaustion from Sydney environmental journalism) led, in 1977 , to the Tuscan region of Italy, where we had opened a restaurant, the Cantina di Toia, still thriving when visited 
three decades later. ${ }^{1}$ Galvanized by vegetable gardens, town markets, old stone hearths, and seemingly universal food enthusiasm, I researched the history of worsening industrial eating back home in Australia for my first book, One Continuous Picnic, which was published in 1982, during the early months of the Aristologist.

With that "gastronomic history of a nation" attracting some interest, I instigated the Australian gastronomic symposiums in 1984; undertook a Ph.D. degree in sociology on the intellectual denial of meals; and launched into further books. Such activities contributed to, and flowed from, running a household business approximating the good life, and not just for us.

Many customers of the Uraidla Aristologist appreciated cooking that respected traditions and seasons, and person-to-person service. Some were put off, however. The whimsical name, which meant that small town's "student of dining," probably announced a sometimes disconcertingly intellectual, even political, earnestness. Our slogan, "Tuscany up Greenhill Road," might have been too obscure. Seemingly more unnerving than any inconsistency in our standards, and long before health regulations, we expected smokers to repair to an adjacent room, or outdoors.

I was particularly struck by a young couple who, after reading our menu, begged forgiveness for leaving for a nearby establishment, because our dishes would be "too spicy." The puzzle was that our cooking was based on Italian and French standards and so gentler than the East-West "fusion" where the diners were headed. The other proprietor would have been first to admit, nonetheless, to seeking approachability.

A popular-sounding name might have signaled a more safely commercial venture. A more predictable menu and on-tap Coca-Cola, or overdecorated dishes and mock servility, would have communicated: the customer is always right. The Aristologist was not going to stop putting meals first, as best we could, but around that time, the ruling ethos moved explicitly behind financial profit. Neoliberalism took hold. Governments acceded to the dictatorship of money. We were meant to obey the Market.

Neoliberalism had taken the stage when the so-called Chicago Boyseconomists mainly trained at the University of Chicago-brought their ideology to Chile, following the coup in 1973. Thatcherism swept into the 


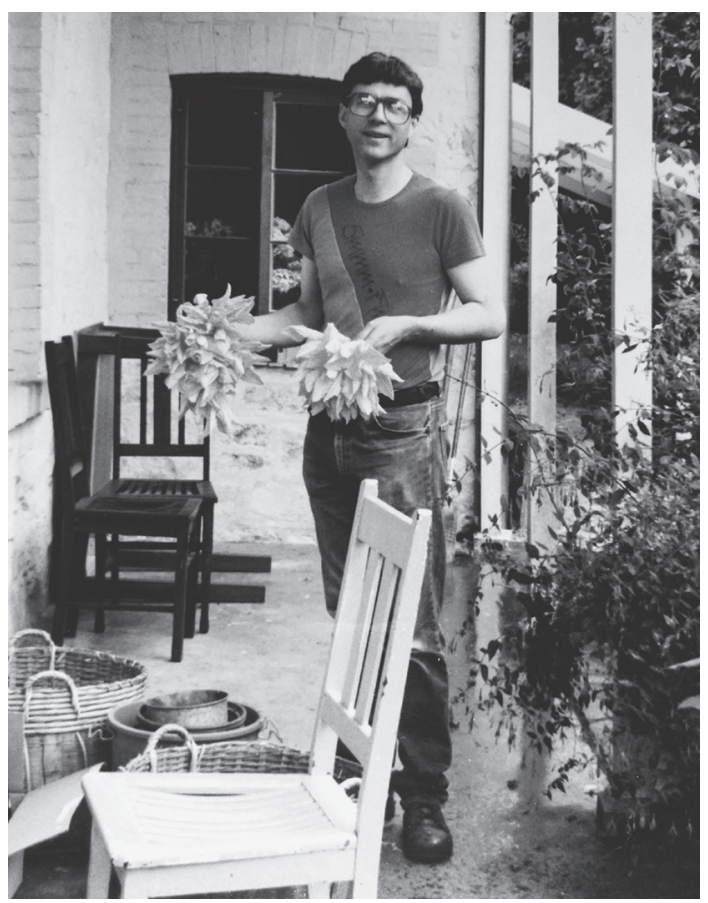

FIGURE 0.1 Author with zucchini flowers, Uraidla Aristologist Restaurant, South Australia, 1982. Photo by author.

United Kingdom from 1975, Reaganomics into the United States in 198I, and Rogernomics into New Zealand from 1984. Australia called it "economic rationalism." The old social contract of equal individuals with rights in democratic republics, and later the welfare state, lost out to privatization, outsourcing, corporate-friendly legislation, high-end tax cuts, and socalled growth. Trade unions were an antiquated impediment. MBAs became glamour degrees. Tearing down the Berlin Wall on November 9, I989, seemed to confirm the triumph of free enterprise, globalization, and restructuring-with no purpose higher than profit.

In Oliver Stone's bitter movie Wall Street (1987), tycoon Gordon Gekko proclaimed, "Greed ... is good." While economists typically spoke of the "rational pursuit of gain," "maximization of net advantages," or "self-interest," the most influential economist of the second half of the 


\section{Prologue}

twentieth century, Milton Friedman of the University of Chicago, campaigned publicly for "greed," claiming that a corporation's entire social responsibility was "to use its resources and engage in activities designed to increase its profits" (1970, 134).

For a while I felt silly. Here we were taking appetites seriously, when, according to economists, think-tanks, and now politicians, only greed counted. Discomfort soon turned to curiosity, however. Why did mainstream economists belittle life-giving systems and support a Midas fantasy? Why ignore the sounds, sights, and smells of actual markets in favor of a mere system of prices? Why this perversion of potentially the most caring of all disciplines-studying the ancient Greek oikos (ecos) or "household"? The new oikonomia or "household management" neglected more than just the domestic but discarded a whole nest of households, still known to seventeenth- and eighteenth-century thinkers.

Over further years of dining and working, I borrowed from intellectual history, social theory, and economics itself to investigate mathematical mystification's tilt at world domination. Eventually, I found neoliberalism had systematically corrupted liberalism, which had a gastronomic basis. Epicurean-influenced philosophers-among the most notable being Thomas Hobbes and John Locke-had understood that self-interested individuals, following their appetites, combined with one another for sustenance. Through the nineteenth century, however, economists transmuted healthy appetites into holy greed. That insanity could best be understood as capitalist logic. Business corporations, programmed for profit, systematically exploited life-giving economies, and economists twisted their theoretical model to suit.

If the upending of liberalism can be demonstrated in a single piece of evidence, it is Adam Smith's often-quoted statement of 1776 about the individual "interest" of the butcher, brewer, and baker. Economics textbooks have routinely misread "interest" as financial. In context, Smith clearly referred to the mutual benefits for the butcher, brewer, and baker of sharing food. Through the "co-operation and assistance of great multitudes ... the butcher, the brewer, or the baker," he wrote, "we expect our dinner." Similarly, in making the market sacred, economics texts employ Smith’s "propensity to truck, barter, and exchange." But they lift 
the market into such a mathematical abstraction, so far above physical sharing, that I capitalize theirs as the Market.

Again, rather than equality being a policy commitment, economics kept it as a merely formal attribute of market players. The laws of mainstream economics apply to all-whether female, straight, white, gay, or a food delivery cyclist. That might sound progressive, except that the most impoverished person is also treated as identical to a global corporation, which might be Nestlé, McDonald's, Privat Group, TripAdvisor, or Saudi Aramco. According to such equality, every individual is charged exactly the same at a luxury resort, although one person might scarcely notice, and another end up in debtors' prison.

Public debt, the finance industry, and the Washington consensus might sound more important than a slice of bread and glass of beer. Yet modern economic thought took off from the exchange between a baker and a brewer, and needs to again. In this book, I restore economics through gastronomic liberalism, reinvigorated.

\section{The Gastronomic Turn}

This radical alternative to neoliberal economics relies on a gastronomic outlook on life. In the years of the Italian sojourn, meals were dismissed in my country as, variously, privileged leisure, self-indulgence, refueling, women's work, or fattening. When One Continuous Picnic (1982) praised fresh foods, I was warned frequently that freshness was a "lost cause." But my book had done something even more outrageous, using meals to explain Australian history, and so convincingly that I both opened and closed with Jean Anthelme Brillat-Savarin's "Tell me what you eat, and I shall tell you what you are." That is the fourth of his twenty aphorisms, designed to get gastronomy underway, and opening his Physiology of Taste that appeared in 1825 .

My preoccupation became Brillat-Savarin's gastronomy. This is the nomos (ancient Greek, law or managing) of the gastêr (stomach, belly, or gut), and an appreciation not only of fine foods but of our whole stomachstructured lives, with the aim of doing better. Ancient Greek philosopher 
Epicurus had said that knowledge and wisdom were ultimately based on the "pleasure of the stomach." Likewise, for Karl Marx, history's "first premise" was "eating and drinking, housing, clothing and various other things." We follow our individual stomachs, and yet, crucially, we are what we eat, together. Rather than compete, diners come together conviviallyfrom the Latin for living together. We seek company - from the Latin for bread-sharing. We want collaboration, community, conversation ... to begin a list of numerous com- or col-, "with" words.

So modernity's puzzling neglect of meals led to doctoral studies into the intellectual disdain for any science of gastronomy (Symons 1992). My undergraduate degree had been in mathematics with its seductive, philosophical idealism. Now I found Epicurean materialism (e.g., Symons 2007a), while sociology taught me that two centuries of rationalization-to borrow sociologist Max Weber's term-had both suppressed gastronomic sensibilities and made them all the more urgent. Fortunately, good gardening, cooking, and dining were soon attracting "foodies." Those paying attention to meals gained that jaunty label in 1982 (the same year as "yuppies"). Foodies are the prospective revolutionaries in this book (that's the "delicious revolution").

One of my dissertation's examiners, a sociologist, required that I remove any reference to a "so-called" new science of gastronomy. ${ }^{2}$ Scholars, however, were generally softening their disapproval and soon added to an existing anthropology of food with food history, food in literature, and the sociology of food, and, from the late r990s, multidisciplinary "food studies." When twenty-six "sociologists, artists, geographers, and cultural, American, and literary studies people" blogged together, they confirmed food studies' complexity, diversity, fluidity—in a word, "mess" (Cook et al. 2011, 105). The bloggers referred to John Law's After Method: Mess in Social Science Research (2004). Not unusually, Law's book made no mention of meals, despite "mess" originally meaning a meal (as in "mess of pottage" and "officers' mess").

In France, Italy, and elsewhere, "gastronomy" usually has come to concern specialist food. But gastronomy can bring together not merely exceptional ingredients but everything. Grandly, in 1825 , Brillat-Savarin ( 1826 , \$18) had envisaged "the systematic knowledge of everything that relates to 
human-beings insofar as they nourish each other." He specified gastronomy's intersections with natural history, physics, chemistry, cookery, and, significantly here, commerce and political economy, and he indeed wrote about "everything" - chocolate, frying, obesity, dreams, death, the end of the world, the artificial life of social influencers, and much more.

Studying "everything" could be messy, especially now that the general store of knowledge has exploded even beyond Google's digital farms. Fortunately, while ambitious, gastronomy is also disciplined, literally adopting a focus (focus, Latin, hearth), which, for me, is meals. Rather than food studies, and food this and that, gastronomy begins more profoundly with meals. Meals plainly involve food and more, and that more brings in society, culture, art, religion, science, technology.... The gastronomic or stomach-centered author takes on (and takes in) the world. Gastronomy provides the diner's sense of the world.

Speaking of the "diner's sense" implies not only a primary focusmeals-but also investigative methods: learning from the senses, and so through empiricism and hedonism. In exemplary manner, Brillat-Savarin made detailed observations and from intimates, for example, discovered that the "truffle is not a positive aphrodisiac; but it can, in certain situations, make women tenderer and men more agreeable” $\left(\$_{44}\right)$. As this quotation suggests, conversation is intrinsic to meals, and so to gastronomical method. The second of Physiology of Taste's twenty aphorisms was "Animals feed; people share meals; and only those with wit know how to dine." 3

Gastronomy provides unparalleled insights into our lives, and that includes into spheres that might appear to have lifted off, such as religion, art, and economics.

\section{Slow-Cooked}

Such was money's rule that, for too long, economics became something they did. With a question, and a general approach to answering it, I eventually realized I had already taken steps toward a more grounded, gastronomic economics-gastronomics. A concluding speculation in my 
sociological dissertation in I991 suggested using "cuisine" for "the entire ensemble of natural and social bodies and forces associated with human sustenance"-close to what I now call an "economy." Next, I protested in The Shared Table (1993) the relegation of the original economics as "mere" home economics. The biggest leap came with my book inquiring into why humans cook (Symons 1998). As Scottish literary biographer James Boswell (1924, I79 n.I) recorded in his journal on August 15, 1773, human beings are the "Cooking Animal." Toolmaking did not separate us from the rest of nature, he wrote. Neither did memory, judgment, nor the faculties and passions. But "no beast is a cook."

When considered at all, the most common theories of cooking are transformational. Like the dictionary meaning, "cook—to prepare (food) by heating," they take their cue from fire, which makes raw ingredients more digestible, tasty, or expressive. For anthropologist Claude Lévi-Strauss (1978, 495), turning the raw into the cooked was a "language." The energy advantages of cooking as predigestion lay behind Richard Wrangham's evolutionary hypothesis in Catching Fire: How Cooking Made Us Human (2009), an idea enshrined in the subtitle of Michael Pollan's Cooked: A Natural History of Transformation (2013).

In 1998, in my history of cooks and cooking, I published another theory. The primary tool was not fire but the much older, Stone Age flints, which evolved into cook's knives, and into such associated implements as hoes, scythes, axes, and cleavers. Cutting up enables sharing of both food and tasks (through exchange and other methods). This distributional theory puts cooking at the center of the division of labor and its products. Sharing food and sharing jobs go together; one demands the other, including not only through families but also, as that book showed, distribution through market exchange, and through government redistribution.

Food redistribution has always been the key responsibility of central administrations. Early in what has been termed "civilization," the first ancient temple-states arose with public kitchens, vast stores of staples, along with great sacrifices to divide up beasts - and these banquets sustained administrators, soldiers, infrastructure workers, and the indigent. Replacing high priests, armed monarchs turned religious feasts into courtly banquets, still in beautifully decorated halls with music. Over time, the 
state's redistribution shifted from contributed foodstuffs to their more flexible substitute, money; but the pooling and disbursement of taxes still served essentially the same function. "Cooks made us," I concluded.

Applying this appreciation of cooking to modern economics, I soon found its gastronomic roots. Rather than the later financially calculative (especially capitalist) direction, eighteenth-century political economists started with the distribution of food and labor, even if they did not always call that a "meal" nor give cooks much credit. As James Steuart put it in An Inquiry Into the Principles of Political CEconomy in London in 1767 , the "principal object of this science is to secure a certain fund of subsistence for all the inhabitants," each person meeting the other's "reciprocal wants" $(2-3)$. How obvious, that economics concerned eating and drinking, rather than profit! Unhappily, economists devised ways to relegate nourishment to mere "utility," "preference," "subjectivity," "externality," or "inefficiency," and to press the abstract Market as the economy. Economists no longer did economics (household management), so much as Aristotle's chrematistics (the science of financial gain). Seeking also to make a distinction, Richard Whately $(1832,6)$ derived catallactics - the "Science of Exchanges." Nevertheless, early in the nineteenth century, practitioners crowded out material concerns by claiming the title "economists" for themselves.

Investigating economists' narrow advocacy of just one social organizing tool-prices-included following up the "Austrian school," who insisted that individuals should strive freely for financial gain, nations should run along business lines, and nature should adjust. Between them, Austrian and Chicago leaders have reset government aims and policies and collected swags of Nobel Prizes, though economics is not an original Nobel category-instead, the Swedish National Bank began sponsoring a special "Sveriges Riksbank Prize in Economic Sciences in Memory of Alfred Nobel” in 1969.

Before the nineteenth century was half done, corporate logic had unleashed "more massive and more colossal productive forces" than previously known, observed Karl Marx and Friedrich Engels in the Manifesto of I848 (chap. I). Profit's insistence on cost-benefit calculation worked wonders of Weberian rationalization, in which traditional authority gave way to bureaucratic. Many consumers benefited, unquestionably, but it was also 
obvious that the "single, unconscionable freedom" - the liberty of moneyhas "torn away from the family its sentimental veil," compelled all nations, "on pain of extinction ... to introduce what it calls civilisation," and subjected "Nature's forces to man." Elevating profits above provisions, and money above other forms of social order ... here was the Market as a demanding God, "rising or falling, plunging or recovering; the subject of emotions-jittery, nervous, buoyant or confident" (Maddox 1998, 106). With money triumphant, liberty no longer meant "down with the king" but "minimal" democracy, leaving real government to industry lobbyists and committees in a toppling, financialized world.

Many progressive economists, such as Nobel-winner Joseph E. Stiglitz (2013), acknowledge that through such nostrums as financial deregulation, tax cuts for the wealthy, and underinvestment in infrastructure, education, health care, and welfare, the wealthy have been "manipulating the system to seize a larger slice." That broadly accords with the Marxist declaration that economic players are divided between owners and nonowners of the means of production.

However, mainstream economists made more sense once I realized, digging further, that their ascetic, moneymaking "individuals" were not people at all. In league with that, the legal system granted corporations a fictitious "personhood" and therefore selected human rights, notably to property and market freedom. This book brings people together against corporations, so alien as to lack the basic economic need to eat and drink. Instead, corporate logic had made money into the supreme rationalizing, antigastronomic force.

\section{A "Total Reconsideration"}

Traversing the modern history of political philosophy and economic theory using gastronomic assumptions, this book charts the appropriation and corruption of liberal ideas by corporation-aligned jurisdictions and mainstream economists, until Market rule unleashed the mocking of liberals, along with their learning, sophistication, and civility. This requires a 
reexamination of the writings of, among others, Hobbes, Locke, Quesnay, Rousseau, and Brillat-Savarin, on one side, and Smith as a bridge to Say, Ricardo, Jevons, Menger, Mises, Robbins, Hayek, Friedman, and Becker, on the other. Other social theorists, including Marx, Weber, Simmel, and Polanyi, are called on, along with more recent investigators. My hope is that this book will encourage scholars across a sweep of disciplines to incorporate further gastronomic interpretations of not merely economics but Epicureanism, liberalism, politics, and society more generally.

To summarize the narrative, Brillat-Savarin's gastronomy, developed here as the diner's sense of the world, emerged from the Enlightenment thought of Hobbes, Locke, Rousseau, and others, who started with the appetite driving individuals to self-preservation in cooperation with others. A presumption of natural equality supported rights to the free pursuit of well-being and its necessary property, under a social contract that supported a democratic commonwealth.

This remained a left-liberalism, inasmuch as equality is both the assumed starting point ("formal equality") and desirable ("substantive equality"). By contrast, nineteenth-century or "classical" liberals and their twentiethcentury "neoliberal" successors wanted competition to generate aspirational inequality. (Certain brands of right-wing politics deny both formal and substantive equality.) Formal equality also lay behind the often unjust "equality before the law" and "legal personhood" of corporations, whose purpose had been sharpened to profit. But how can we grant corporations human rights when they do not even eat?

Supporting the transcendence of fundamental human needs, including within scholarship, nineteenth-century or "neoclassical" economists rationalized interpersonal interactions, so that equal individuals bought and sold in no physical market but in a formal Market-a system of prices. The rational, gain-seeking player is an artificial person acting like a corporation, summed up as Homo economicus.

In response, gastronomic economics emphasizes that we rely on multiple levels of households. We in no way live in a single, "the economy," especially not as a mere system of debits and credits. Enlightenment intellectuals were familiar with the original or "domestic" economy and extended 


\section{Prologue}

that by speaking, by analogy, of the "political economy." This was also known as the "body politic" because the human body circulated nourishment internally as an "animal economy" within the overall "natural economy."

In recent times, numerous small food producers, artisans, homemakers, waiters, baristas, and eaters have rejected the economics of greed in favor of an economics of appetite. Such meal-lovers get back to basics with fresh, local, and "slow" foods, street markets, school gardens, urban farms, and action on sustainability. They base domestic life on meal sharing and call for food justice in a new, global banquet. In knowing that we are what we eat, together, the left-liberal enthusiasms of foodies might yet rescue us. That includes the social sciences, which for too long joined philosophy in dismissing eating and drinking as unworthy.

While many readers will be familiar with aspects, they might still be surprised how far, from a gastronomic starting point, "classical" liberal lawmakers and "neoclassical" and "neoliberal" economists have twisted our world. The high theology of the Market is so pervasive that it can affect even stern critics. In The Livelihood of Man, economic historian Karl Polanyi (1977, xliii, xlvi) recognized decades ago that to improve civilization's "chances of survival, the problem of man's material livelihood should be subjected to total reconsideration." The "chief impediment," he said, was the absolute priority given to the "motive of economic gain." Gastronomy must undertake Polanyi's rethink by avoiding his narrow understanding of "economic" in that quotation. Likewise, politicians swallowed "It's the economy, stupid," also as if it means money. The answer, involving several economies, lies in front of our noses.

More recently, in Undoing the Demos, political theorist Wendy Brown (2015, 3I, 35, 4I, 22I-22) vividly portrayed neoliberalism's "relentless and ubiquitous economization of all features of life." In disseminating "the model of the market to all domains and activities," neoliberal rationality hollowed out people as Homo economicus and recast the "state as the manager of a firm." Since markets now "know best," everyone was caught on the "perpetual treadmill of a capitalist economy that cannot cease without collapsing." Even the Left suffered ubiquitous "civilizational despair," she wrote. Brown's pessimism flowed from her acceptance that "economization" is total, rather than just a forceful ideology that mistakes 
money for meals, corporations for diners, and prices for economies. While there's life, there's hope. By the epilogue, I recommend the ancient expression of tangible togetherness, "eat, drink, and be merry."

English columnist George Monbiot (2016) observed that neoliberal thinkers and activists were ready with a clear alternative when the inadequacies of Keynesian economics became apparent in the 1970s, just as Keynes had been prepared when laissez-faire economics led to catastrophe in 1929. Monbiot did not want a reprise of Keynes's stimulation of consumer demand to promote economic growth-these were the "the motors of environmental destruction." But he had no response, given that the "left and centre have produced no new general framework of economic thought for 80 years." Designing a replacement system to prevailing neoliberalism would require a left-leaning "Apollo programme."

Having taken an embarrassing number of years, this research has felt like an Apollo program. Not that I have invented much; instead, I have brought together established elements of economic theory, social and cultural theory, political philosophy, and intellectual history. The result might not look like conventional economics, but that's the book's strength: it reestablishes the basics. The neglected discipline of gastronomy regrounds theory, making it literally radical. The answer to the Market is not better metaphysics but knowing that meals matter. Meals are complex and manyfaceted but also recurring, so they offer repeated opportunities to get them right-yet again within hours. Recent micro- and macroeconomics are useful but, like even the most wonderful kitchen scales, minor contributors to the merriment. Restraining recent mathematics to a technical subbranch, gastronomic economics—gastronomics—makes the "dismal science" smile again. Our world, afresh.

Academically, my immediate intention with this book is to investigate the exceedingly inflated claims of mainstream economics. From the associated necessity of outlining an alternative, I recover the Enlightenment version, based in more authentically economic concerns. Along with that, my hope is to persuade scholars in more established disciplines to further resist money's rationalization of the world, and to help restore a diner's sense of things. If that happens also to further gastronomy, so be it. 


\section{Prologue}

Methodologically, this book is unapologetically gastronomic. BrillatSavarin's foundational text, Physiology of Taste, might appear disorganized, but, given its topic and transdisciplinary requirements, a gastronomic work must be forgiven for erring on the side of the conversational, mixing wit with gravity. ${ }^{4}$ Given the gastronomic regrounding, some words might have unexpected uses, hence the glossary at the end of the book. If a description of a meal happens to set the table for each of the following chapters, then that is because talking about meals talks about the world. 


\section{MEALS MATTER}


